\title{
Towards a cashless society: Use of electronic payment devices among generation $Z$
}

\section{Raden Aswin Rahadia , Yunieta Anny Nainggolan ${ }^{a}$, Kurnia Fajar Afgania, Mohd Yusoff Yusliza ${ }^{b^{*}}$, Juhari Noor Faezah ${ }^{b}$, Thurasamy Ramayah ${ }^{\text {c,de, }}$, Jumadil Saputra ${ }^{\mathrm{b}}$, Zikri Muhammad ${ }^{\mathrm{b}}$, Khalid Farooq $^{b}$ and Chyntia Angelina ${ }^{a}$}

${ }^{a}$ School of Business and Management, Institut Teknologi Bandung, Bandung 40132, West Java, Indonesia

${ }^{b}$ Faculty of Business, Economics and Social Development, Universiti Malaysia Terengganu, 21030 Kuala Nerus, Terengganu, Malaysia ${ }^{c}$ School of Management, Universiti Sains Malaysia, 11800 USM, Penang, Malaysia

${ }^{d}$ Internet Innovation Research Center, Minjiang University, A212, Newhuadu Business School, Minjiang University, 200 Xiyuangong Road, Shangjie

Town, Minhou County, Fuzhou, Fujian, China

${ }^{e}$ Department of Management, Sunway University Business School (SUBS), 5, Jalan Universiti, Bandar Sunway, 47500 Selangor, Malaysia

\section{H R O N I C L E}

\section{Article history:}

Received: June 18, 2021

Received in revised format: June

29,2021

Accepted: September 22, 2021

Available online: September 22,

2021

Keywords:

Actual usage

Continuance usage intention

Effort expectancy

Electronic payment

Facilitating conditions

Performance expectancy

Social influence

\section{A B S T R A C T}

\begin{abstract}
Nowadays, transactions on e-commerce platforms (e-payment) utilizing a credit card are popular. Using credit cards for electronic purchases over the Internet is much different from offline purchases in traditional stores; only online transactions do not include either physical credit card or a signature. The e-payment has become a common mode of payment for online transactions made. It is an electronic billing system that gives clients the ability to make payments using the Internet. The objective of this paper was to analyze the associations among continuance intention e-payment, effort expectancy, facilitating conditions, performance expectancy, social influence, and actual usage of e-payment. The data was tested empirically on data collected from 667 Generation Z e-payment users in Malaysia. The results found that facilitating conditions, performance expectancy, and social influence impacted the actual usage of e-payment. Surprisingly, effort expectancy was not significantly associated with the actual e-payment usage. The findings of this study have several implications for managers and point the way towards future research. No prior empirical study has investigated the role of the Unified Theory of Acceptance and Use of Technology model on e-payment usage among Generation $\mathrm{Z}$ in Malaysia to the best of the authors' knowledge. These results provide valuable contributions that can help decision-makers formulate or adjust their strategies associated with e-payments.
\end{abstract}

\section{Introduction}

Knowing the impacts that technological advances cause in people's everyday lives has sparked the attention of many scholars in the social sciences (de Sena Abrahão et al., 2016). Advances in technology have also created a wide variety of different functionalities for mobile apps, enabling several mobile financial applications like bill paying, wallet transactions, person-toperson transactions, point-of-sale proximity payments, online payments for purchases of products and services, and other services like location-based services, mobile ads, ticketing, promotions or co-operative services (Oliveira et al., 2017). The explosive rise of communication and information technologies has brought the world into a new age of intangible ways that enable online payments (Acheampong et al., 2017). In addition, the increasing usage of social networks like Facebook,

* Corresponding author.

E-mail address: yusliza@umt.edu.my (M. Y. Yusliza)

(C) 2022 by the authors; licensee Growing Science, Canada. doi: $10.5267 /$ j.ijdns.2021.9.014 
LinkedIn, and Twitter has created possibilities for new business models in the online commerce sector, also referred to as social trade (Liébana-Cabanillas et al., 2018).

Today, e-payment has become a common mode of payment for online transactions made (Teoh et al., 2013). E-payment is an electronic billing system giving clients the ability to make payments using the Internet (Tella \& Olasina, 2014). Transactions on e-commerce platforms utilizing a credit card are popular today (Kurniawati et al., 2020). Using credit cards for electronic purchases over the Internet is much different from offline purchases in traditional stores (Fedorko et al., 2018) because online transactions do not require either a physical credit card or a signature card (Junadi, 2015). Like payment patterns in other nations, Malaysia's payment environment has also shifted and developed over the past decades, with more accelerated recent changes due to globalization and technical advancement (Lee et al., 2013; Muhammad et al., 2019).

According to Herrando et al. (2019), Generation Z applies to the younger group, born between 1991 and 2000. Encouraging this generation to use their own technology is also essential (Shatto \& Erwin 2017). Generation $Z$ is sometimes called the "generation of the internet." The individuals of this group are members of various networks, which are often distinct from previous generations (Ozkan \& Solmaz 2015). Hence, investigating the continuance usage behavior of e-payment users in this generation is significant for researchers and practitioners.

Since 2017, the importance of continuance intention research has increased noticeably among scholars (Cao \& Niu, 2019; Garcia et al., 2019; Huang, 2020; Ofori et al., 2017). Continuance intention is the willingness of the users to focus on using an application related to technology like mobile money transfer services. Actual use refers to the transition from a user's purpose in using a service to when a user utilizes a technology (Mensah et al., 2020). For instance, users accustomed to booking hotels via online reservation websites and accessing such websites daily are often called users who utilize online reservations on an ongoing basis. This trend may be viewed as a post-acceptance stage in the diffusion model of innovation, where users have embraced, started to use, or even injected the technology (Cho et al., 2009). Previous studies have examined continuance intention in various Internet environments (Asnakew, 2020; Choi et al., 2019; Khwaldeh, 2020; Mensah et al., 2020), but the current study focuses on e-payment usage research.

This current study makes two primary contributions to the research on e-payment usage. First, unlike prior studies that have been concerned primarily with the use of mobile payments and online banking (Chaouali et al., 2016; Poromatikul et al., 2019), this study focuses on the use of e-payment by users and utilizes the UTAUT model to investigate the continuance intention of e-payment users. This focus deepens the comprehension of e-payment continuance usage behavior. Second, this research extends the UTAUT model in understanding the drivers ensuring the success of e-payment devices. Exploring these factors is essential, especially in the Malaysian environment, given the exciting innovations currently taking place and the expectation that e-payment usage will expand substantially over the next few years (Teoh, Chong, Lin \& Chua, 2013). This article is organized as follows. First is an overview of the literature concerning the linkages between facilitating conditions, effort expectancy, performance expectancy, social influence, actual usage of e-payment, and continuance intention of e-payment.; next, the hypotheses to be tested are posited. Then, the research method is outlined, following which is a discussion of the analysis and results. Finally, a discussion of the study's findings concludes the study.

\section{Literature Review}

\subsection{Theoretical Background}

The UTAUT was drawn upon to examine and explain e-payment use among Generation Z members in Malaysia. This model proposes that four constructs impact behavioral intention and actual use of technology. These are 1) effort expectancy (similar to complexity and perceived ease of use), 2) facilitating conditions (similar to perceived behavioral control), 3) performance expectancy (perceived usefulness and relative advantage), and 4) social influence (similar to the subjective norm) (de Sena Abrahão, Moriguchi \& Andrade, 2016; Foster, Saputra \& Grabowska, 2020; Thakur \& Srivastava, 2014).

In the UTAUT model, these four constructs affect the behavioral intention to use a technology, while behavioral intention and facilitating conditions evaluate the use of technology (Junadi, 2015). According to Maillet, Mathieu and Sicotte (2015), these frameworks concentrate on the expectations of users of the utility of a system for improving its effectiveness, the ease with which they can learn how to utilize a system, the role of significant individuals in the work environment in shaping the actions of end-users, and, finally, the steps taken to promote improvement. This current study adapted constructs and definitions from the UTAUT model to Generation Z technology acceptance and use. The section below deals with the hypothesis's formulation utilizing the UTAUT as a theoretical perspective to construct arguments and proposes several hypotheses to be examined empirically.

\subsection{Performance Expectancy and Actual Usage of e-Payment}

Performance expectancy of use is a feature of a person's general view of how convenient a new technology is going to be (Acheampong, Zhiwen, Antwi, Otoo, Mensah \& Sarpong, 2017; Al-Qeisi, Dennis, Alamanos \& Jayawardhena, 2014; Humbani \& Wiese, 2019; Keong, Ramayah, Kurnia \& Chiun, 2012). Performance expectancy reflects the perceived utility 
related to using an e-payment (Zhou, 2011). According to Zhou (2014), performance expectations reflect the value extracted from the usage of mobile payments. In particular, it applies to the assumption that utilizing an e-payment will be effortless (Chang, Hung, Cheng \& Wu, 2015; Phan, Tran, Hoang \& Dang, 2020; Riskinanto, Kelana \& Hilmawan, 2017; Tella \& Olasina, 2014). Performance expectancy and confirmations from previous use have a huge effect on users' happiness when implementing and using a product (Susanto, Chang \& Ha, 2016). Once individuals have built confidence in online payments, they are less concerned about payment risk and confusion. Junadi (2015) and Zhou (2014) provided empirical evidence that performance expectancy significantly impacts the actual e-payment usage.

Previous studies also support the conclusion that once users believe that the degree of program effectiveness is sufficiently high, they are more trusting and able to adopt a system (Kaium, Bao, Alam \& Hoque, 2020). Consequently, the belief of a user that employing e-payment would help to make improvements in the performance of payment tasks affects the behavioral purpose of implementing an e-payment (Goyal, Maity, Thakur \& Srivastava, 2013; Oliveira, Thomas, Baptista \& Campos, 2016). Qasim and Abu-Shanab (2016) argued that performance expectancy was a significant predictor of e-payment adoption. Recently, Isaac, Abdullah, Aldholay and Ameen (2019) demonstrated the positive effect of performance expectancy on actual Internet usage among employees in Yemen. Theoretically, several different studies have supported the impactful role of performance expectancy on usage behavior directly toward using e-payments (Chopdar, \& Sivakumar, 2019; Marinković, Đorđević \& Kalinić, 2020a; Mensah, Chuanyong \& Zeng, 2020). Users might continue to use an e-payment service if they find it useful, even if they were disappointed with their previous usage (Khayer \& Bao, 2019; Tella \& Olasina, 2014). Hence, the following hypothesis is posited:

\section{$\mathbf{H}_{1}$. Performance expectancy positively influences the actual usage of e-payment.}

\subsection{Effort Expectancy and Actual Usage of e-Payment}

In the setting of the current study, effort expectancy represents the challenges in utilizing an e-payment system (Zhou, 2011). Effort expectancy is the ease of use related to the technical features of a system. Potential users would be more willing to adopt and implement a system that is easy to use with simply understood technical features (Chong, Chan \& Ooi, 2012; Keong, Ramayah, Kurnia \& Chiun, 2012; Lin \& Nguyen, 2011; Phan, Tran, Hoang \& Dang, 2020). Additionally, systems with lower effort expectancy have user-friendly interfaces, relevant content and graphical templates, useful functionalities, consistent instructions, and easily understood error messages (Lin \& Nguyen, 2011). These features mean that once a person understands that few resources are required to understand a new mobile device, he or she will interpret the device as valuable, leading to its continued use (Humbani \& Wiese, 2019).

Past studies have evidenced that effort expectancy had a significant impact on the actual e-payment usage (Goyal, Maity, Thakur \& Srivastava, 2013; Maillet, Mathieu \& Sicotte, 2015; Riskinanto, Kelana \& Hilmawan, 2017). Qasim and AbuShanab (2016) indicated that effort expectancy typically tends to be of more considerable significance in early adoption, and a well-disseminated and approved technical infrastructure boosts efficiency and work results (Acheampong, Zhiwen, Antwi, Otoo, Mensah \& Sarpong, 2017). Furthermore, Isaac, Abdullah, Aldholay and Ameen (2019) suggested that effort expectancy positively impacted the actual usage of the Internet. This relationship means that the more users believe that an e-payment device would be easy to use, the more they would continue to use that device in the future. Hence, the following hypothesis is posited:

\section{H2. Effort expectancy positively influences the actual usage of e-payment.}

\subsection{Social Influence and Actual Usage of e-Payment}

Social influence is used about the impressions that an individual perceives from significant other people about an action, which impacts whether he or she will engage in an action (Kijsanayotin, Pannarunothai \& Speedie, 2009). The degree to which a person perceives that significant others think he or she should employ a technology is a social impact (Kaium, Bao, Alam \& Hoque, 2020). Social influence is firmly rooted in technology adoption models and, more generally, in user behavior models (Koenig-Lewis, Marquet, Palmer \& Zhao, 2015). In a study among university students, Chaouali, Yahia and Souiden (2016) discovered that a person who feels that significant people (e.g., family and friends) consent to his or her usage of new products, goods, or services may be more willing to accept and support such products and services. Thus, as Phan, Tran, Hoang and Dang (2020) have highlighted, most agree that social influence is a significant factor.

Indeed, social impact has had a strong influence on intention, indicating that peer perception serves a critical function in adopting mobile wallet services (Koenig-Lewis, Marquet, Palmer \& Zhao, 2015). For example, Isaac, Abdullah, Aldholay and Ameen (2019) showed that social influence has a positive relationship with actual Internet usage. Past studies have also confirmed that social influence significantly influences actual e-payment usage (Junadi, 2015; Keong, Ramayah, Kurnia \& Chiun, 2012). The findings highlighted the level of initiative and social impact as key predictors and listed time and technological assistance as major obstacles to adopting and using technology (de Sena Abrahão, Moriguchi \& Andrade, 2016). Built a review of the extant literature, the following hypothesis is posited: 
H3. Social influence positively influences the actual usage of e-payment.

\subsection{Facilitating Conditions and Actual Usage of e-Payment}

According to Mun, Jackson, Park and Probst (2006), facilitating conditions refer to the perception of internal and external limits on behavioral efficiency. Additionally, a facilitating condition is characterized as the degree to which an individual assumes that an organizational and technological framework exists to facilitate the usage of a system (Escobar-Rodríguez \& Carvajal-Trujillo, 2014; Keong, Ramayah, Kurnia \& Chiun, 2012; Kijsanayotin, Pannarunothai \& Speedie, 2009). Zhou (2011) highlighted that a facilitating condition ensures people have the requisite tools and skills to access the mobile Internet. The prerequisite for users to approve either the use or trial of any good, product, or service is that a new product is practical and easy to use for those who expect to use the good, product, or service (Thakur \& Srivastava, 2014). In their review of past studies, Alalwan, Dwivedi and Rana (2017) found that users would also be more likely to use e-payment because they have a certain amount of service and ability and view an e-payment as consistent with a specific technology that they currently utilize. Teo, Tan, Ooi, Hew and Yew (2015) elaborated that facilitating conditions characterized users with the ability to customize and run cell phones to access the wireless Internet. When users do not possess these tools and information, they will not want to use an e-payment device (Zhou, 2011).

Additionally, UTAUT suggested a strong influence of perceived facilitating conditions to accept any new technology (Thakur \& Srivastava, 2014). If more facilitating conditions exist that encourage the usage of technologies, then individuals will be more willing to embrace the technologies (Im, Hong \& Kang, 2011; Oliveiraa, Fariaa, Thomas \& Popovica, 2014). Users may not want to use mobile technology unless they have the knowledge, resources, and skills required to do so (Kaium, Bao, Alam \& Hoque, 2020). Furthermore, Oh and Yoon (2014) demonstrated that facilitating conditions are the variables that are theorized as having a direct effect on system use. Keong, Ramayah, Kurnia and Chiun (2012) suggested the effect of promoting requirements on the usage of the e-payment by end-users can be further decomposed into considerations that have the same goal of tapping the connection between an individual's working style and the usage of a system in an organization. Thus, the following hypothesis is posited:

\section{H4. Facilitating conditions positively influence the actual usage of e-payment.}

\subsection{Actual Usage and Continuance Intention of e-Payment}

Actual usage relates to the amount of time that a user spends with a technology (Tella \& Olasina, 2014). Huang (2020) elaborated that individuals must use an information system to determine whether their continuing intentions to use an information system are high or low. In a study among Internet users in China, Gao, Waechter and Bai (2015) discovered that when users encounter an ideal experience, they can feel great pleasure and hope to have the experience again. Therefore they will continue to use it (Humbani \& Wiese, 2019). Looking not only at the implementation of these programs but also at their continuance is necessary (Tan \& Chen, 2008). Accordingly, the desire to participate and continue using e-payment characterizes e-payment continuity (Tella \& Olasina, 2014). Extensive research has utilized the UTAUT model to a variety of digital innovations like e-payments (Junadi, 2015; Riskinanto, Kelana, \& Hilmawan, 2017), mobile Internet (Chopdar \& Sivakumar, 2019; Marinković, Đorđević \& Kalinić, 2020b; Mensah, Chuanyong \& Zeng, 2020; Odoom \& Kosiba, 2020) and online banking (Al-Qeisi, Dennis, Alamanos \& Jayawardhena, 2014; Chaouali, Yahia \& Souiden, 2016).

Additionally, Susanto, Chang and Ha (2016) highlighted that if a good or service has been purchased, then a person's preferences will decide his or her level of fulfilment and potential desire to repurchase. A software is context-aware as it uses information to provide a user with appropriate knowledge or resources, and relevance depends on the role of the user (Cao \& Niu, 2019). Hence, UTAUT might be more valuable for examining the actual information systems continued usage behavior instead of examining the continued intention of using an information system when the information system is organizationally mandated.

Along the same lines, Korzaan and Morris (2009) indicated that continuance intention taps into people's behavioral inclination or willingness to continue spending capital, energy, and time. In addition, the continuance usage intention of IT users has suggested that users gain anticipated benefits across the implementation, which has a positive impact on user and performance expectancy (Kaium, Bao, Alam \& Hoque, 2020; Muangmee, Kot, Meekaewkunchorn, Kassakorn \& Khalid, 2021). Most research has evaluated the behavioral intention to use a system before a system is implemented, using this variable as a surrogate for actual use (Ginanjar, Hurriyati, Adiwibowo, Gaffar \& Saputra, 2019; Maillet, Mathieu \& Sicotte, 2015). The underlying theory of current information system research on the use of technologies is that the sustenance engine is the continuous usage of an information system device or service (Osah \& Kyobe, 2017). Using an information system affects user continuance intentions (Ofori, Boateng, Okoe \& Gvozdanovic, 2017). If an operating system exists and promotes the usage of e-payments, then there would be an improvement in the actual usage to a continuance to accept e-payments (Oliveira, Thomas, Baptista \& Campos, 2017; Tella \& Olasina, 2014). Consequently, the following hypothesis is posited:

\section{H5. Actual usage positively influences the continuance intention of e-payment.}




\subsection{Research Framework}

Fig. 1 shows the theoretical framework for this study.

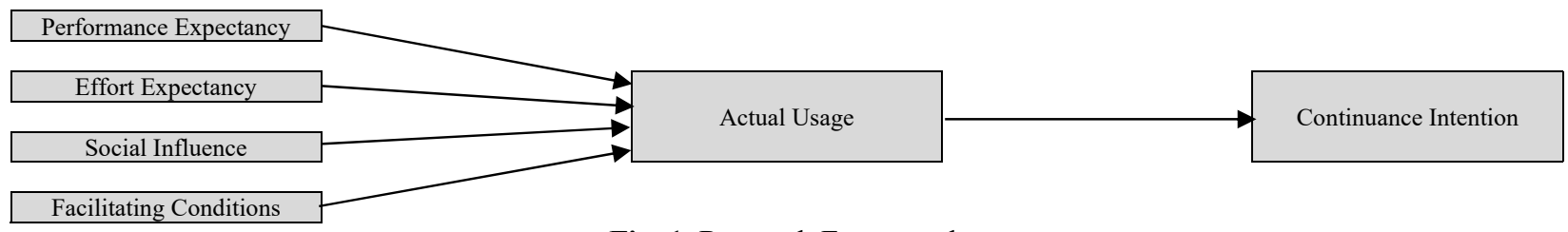

Fig. 1. Research Framework

\section{Materials and Methods}

\subsection{Sample and Procedure}

This study examined the association among effort expectancy, facilitating conditions, performance expectancy, social influence, actual use of e-payment, and continuance intention of e-payment through a correlational research design. A survey instrument was developed with measurement scales to test the research model. An online survey was distributed through social media platforms in Malaysia in April 2020, using snowball sampling. The participating respondents were requested to complete a survey to measure their electronic e-payment usage. A total of 667 completed questionnaires were gathered that were usable for further analysis.

\subsection{Questionnaire Items}

An online survey comprising 27 questions, which had two parts, was utilizes for the empirical collection of data. The first part comprised eight close-ended questions to determine demographic variables using a nominal scale (types of e-payment, gender, age, race, e-payment systems usage frequency, e-payment system experience, educational level, and marital status). The second part contained the UTAUT model items. Use behavior was measured by using a four-item scale that adapted from Gupta and Arora (2019). Performance expectancy (four items), effort expectancy (four items), social influence (three items) and facilitating conditions (four items), continuance intention to use e-payment (three items) were adapted from Venkatesh, Thong and $\mathrm{Xu}$ (2012). The survey questionnaire was rated on a 6-point Likert-type scale in which values ranged from $1=$ strongly disagree to $6=$ strongly agree.

\section{Results}

\subsection{Demographics}

Of the 667 respondents, $74.2 \%$ were female, and $25.8 \%$ were male. Most respondents $(32.4 \%)$ were born in 1999 , followed by $31.0 \%$ in $1998,16.6 \%$ in $16.6 \%, 14.7 \%$ in $2000,2.8 \%$ in $1996,1.9 \%$ in 1995 , and only $0.4 \%$ in 2001 . Moreover, the respondents were predominantly Malay $(88.6 \%)$, followed by Chinese (3.7\%), Indian (3.7\%), and others such as Bumiputera Sabah and Sarawak (4.0\%). Concerning marital status, $99.1 \%$ of the respondents were single, and $0.9 \%$ were married.

\subsection{Measurement Model}

Structural Equation Modelling (SEM) analysis with AMOS 26 was utilized to estimate the model in two stages (Anderson \& Gerbing, 1988): the measurement and structural models for measurement quality and model fit. For measurement quality, the study followed the recommendations of $\mathrm{Hu}$ and Bentler (1999) and Hair, Babin and Krey (2017) by examining construct reliability, convergent validity, and discriminant validity. For a good model fit, the Chi-square normalized by degrees of freedom $\left(\chi^{2} / \mathrm{df}\right)$ should not be more than 3 , the goodness of fit index (GFI) should be more than 0.9 , the adjusted goodness of fit index (AGFI) should be more than 0.8, the non-normed fit index (NNFI) should be more than 0.9, the comparative fit index (CFI) should be more than 0.9, and the root mean squared error (RMSEA) should be less than 0.08. In the CFA analysis the p-value was significant, $\chi^{2} / \mathrm{df}$ was $2.982\left(\chi^{2}=518.919, \mathrm{df}=174\right), \mathrm{GFI}=0.930, \mathrm{AGFI}=0.908, \mathrm{CFI}=0.968, \mathrm{TLI}=0.961$ and RMSEA $=0.055$ suggesting adequate model fit.

Next, measurement quality was judged by examining the average variance extracted (AVE), composite reliability (CR), and loadings. Good measurement quality is exhibited when loadings $\geq 0.7, \mathrm{AVE} \geq 0.5$ and CR $\geq 0.7$ (Ramayah, Cheah, Chuah, Ting \& Memon, 2018). As shown in Table 1, all loadings were more than 0.7 (except one item = FC4), AVE was more than 0.5 , and CR was more than 0.7 . Therefore, the convergent validity and the reliability of the measurement items were acceptable. 
Table 1

The result of construct validity and reliability

\begin{tabular}{|c|c|c|c|c|}
\hline Construct(s) & Item(s) & Loadings & $\mathrm{CR}$ & AVE \\
\hline \multirow{4}{*}{ Performance Expectancy } & PE1 & 0.846 & \multirow{4}{*}{0.883} & \multirow{4}{*}{0.655} \\
\hline & PE2 & 0.793 & & \\
\hline & PE3 & 0.882 & & \\
\hline & PE4 & 0.706 & & \\
\hline \multirow{4}{*}{ Effort Expectancy } & EF1 & 0.860 & \multirow{4}{*}{0.919} & \multirow{4}{*}{0.74} \\
\hline & EF2 & 0.870 & & \\
\hline & EF3 & 0.879 & & \\
\hline & EF4 & 0.832 & & \\
\hline \multirow{3}{*}{ Social Influence } & SI1 & 0.847 & \multirow{3}{*}{0.907} & \multirow{3}{*}{0.765} \\
\hline & SI2 & 0.880 & & \\
\hline & $\mathrm{SI} 3$ & 0.896 & & \\
\hline \multirow{4}{*}{ Facilitating Condition } & $\mathrm{FC1}$ & 0.830 & \multirow{4}{*}{0.876} & \multirow{4}{*}{0.641} \\
\hline & $\mathrm{FC} 2$ & 0.873 & & \\
\hline & FC3 & 0.827 & & \\
\hline & $\mathrm{FC} 4$ & 0.654 & & \\
\hline \multirow{3}{*}{ Usage Behavior } & UB2 & 0.825 & \multirow{3}{*}{0.824} & \multirow{3}{*}{0.613} \\
\hline & UB3 & 0.656 & & \\
\hline & UB4 & 0.853 & & \\
\hline \multirow{3}{*}{ Continue Usage } & CI1 & 0.831 & \multirow{3}{*}{0.893} & \multirow{3}{*}{0.737} \\
\hline & $\mathrm{CI} 2$ & 0.884 & & \\
\hline & $\mathrm{CI} 3$ & 0.859 & & \\
\hline
\end{tabular}

Note: $\quad$ Item UB1 was deleted due to low loadings.

Many researchers have used Fornell and Larcker, (1981) method for assessing discriminant validity, but Kline (Henseler, Ringle \& Sarstedt, 2015) recently suggested that this method was not very good at measuring misspecified models. As such, they recommended the Heterotrait-Monotrait (HTMT) ratio of the correlations approach for assessing discriminant validity. The suggestions were to use an $\mathrm{HTMT}_{0.85}$ or $\mathrm{HTMT}_{0.90}$ threshold for assessing discriminant validity. If the calculated ratios were lower than 0.85 (stricter) or 0.90 (lenient), then the measures are discriminant. If not, they are not discriminated against.

Table 2

The result of discriminant validity using Heterotrait-Monotrait (HTMT) ratio

\begin{tabular}{clccccc}
\hline No & \multicolumn{1}{c}{ Construct(s) } & 1 & 2 & 3 & 4 \\
\hline 1 & Performance Expectancy & & & & \\
2 & Effort Expectancy & 0.831 & & & \\
3 & Social Influence & 0.636 & 0.557 & & \\
4 & Facilitating Conditions & 0.794 & 0.850 & 0.659 & 0.594 & 0.639 \\
5 & Usage Behavior & 0.577 & 0.548 & 0.521 & 0.864 \\
6 & Continue Usage & 0.644 & 0.592 & 0.520 & 0.639 \\
\hline
\end{tabular}

Table 2 displays the result of discriminant validity using the Heterotrait-Monotrait (HTMT) ratio. The result indicated that all the ratios were lower than 0.90 ; thus, the measures used in this study are discriminant.

\subsection{Structural Model}

Mardia's coefficient for multivariate kurtosis was $307.99(\mathrm{p}<0.01)$, and Kline $(2012)$ said that values above 20 indicated that the data are not multivariate normal. Thus, a Bollen Stine bootstrapping with 5,000 resamples was run to produce the standard errors for hypothesis testing. First, the model fit was assessed. The $\chi^{2} / \mathrm{df}$ was $2.980\left(\chi^{2}=517.697, \mathrm{df}=178\right)$, GFI $=0.931$, $\mathrm{AGFI}=0.911, \mathrm{CFI}=0.969, \mathrm{TLI}=0.963$ and $\mathrm{RMSEA}=0.054$ suggesting adequate model fit. The $\mathrm{R}^{2}$ for Usage Behavior was 0.444, and for Continuance Intention, the $\mathrm{R}^{2}$ was 0.767 . The four predictors explained $44.4 \%$ of the variance in Usage behavior, with Performance Expectancy $(\beta=0.273, p<0.01)$, Social Influence $(\beta=0.183, p<0.01)$ and Facilitating Conditions $(\beta$ $=0.290, \mathrm{p}<0.01)$ were positively related to Usage behavior while Effort Expectancy $(\beta=0039, \mathrm{p}>0.05)$ was insignificant (see Table 3). This supports H1, H3 and H4 while H2 was not supported. Usage behavior $(\beta=0.751, \mathrm{p}<0.01)$ was positively related to Continuance Intention explaining $76.7 \%$ of its variation.

Table 3

The result of hypothesis testing

\begin{tabular}{|c|c|c|c|c|c|c|}
\hline Hypothesis & Path & Unstd. Beta & Std. Beta & Std. Error & t-values & p-values \\
\hline $\mathrm{H} 1$ & $\mathrm{PE} \rightarrow \mathrm{UB}$ & 0.273 & 0.257 & 0.082 & 3.338 & $\mathrm{p}<0.001$ \\
\hline $\mathrm{H} 2$ & $\mathrm{EE} \rightarrow \mathrm{UB}$ & 0.039 & 0.038 & 0.092 & 0.423 & $\mathrm{p}<0.672$ \\
\hline $\mathrm{H} 3$ & $\mathrm{SI} \rightarrow \mathrm{UB}$ & 0.183 & 0.191 & 0.048 & 3.788 & $\mathrm{p}<0.001$ \\
\hline $\mathrm{H} 4$ & $\mathrm{FC} \rightarrow \mathrm{UB}$ & 0.290 & 0.265 & 0.090 & 3.211 & $\mathrm{p}<0.001$ \\
\hline $\mathrm{H} 5$ & $\mathrm{UB} \rightarrow \mathrm{CI}$ & 0.751 & 0.876 & 0.037 & 20.176 & $\mathrm{p}<0.001$ \\
\hline
\end{tabular}

Note: Performance Expectancy (PE), Effort Expectancy (EE), Social Influence (SI), Facilitating Conditions (FC), Usage Behavior (UB), Continue Usage Intention $(\mathrm{CI})$ 


\section{Discussion}

This section concentrates on the study's primary findings, discussing the research objectives, the implications of the results, the limitations of the research, and directions for future research. This paper offered a framework for evaluating the factors influencing the use of e-payment among Generation $\mathrm{Z}$ users in Malaysia. This study investigated the relationship of the UTAUT model on actual e-payment usage. The findings confirm the effectiveness of performance expectancy on actual usage of e-payment. This result is consistent with extant research findings (e.g., Chang, Hung, Cheng \& Wu, 2015; Khayer \& Bao, 2019; Riskinanto, Kelana \& Hilmawan, 2017; Tella \& Olasina, 2014; Zhou, 2014). Zhou (2014) indicated that when users evaluate their continued use of mobile payments, they are interested in gaining a positive benefit and in having an engaging experience. Phan, Tran, Hoang and Dang (2020) further contended that the degree of value that e-payments offer to the success of payment activities significantly affects e-payment adoption. The impact of performance expectancy also aligns with the findings of previous research (Goyal, Maity, Thakur \& Srivastava, 2013; Junadi, 2015; Kaium, Bao, Alam \& Hoque, 2020; Susanto, Chang \& Ha, 2016). Viewed through the lens of the UTAUT model, the results also support the importance of the perspective of users that their efficiency and transactions can be enhanced through e-payments (Isaac, Abdullah, Aldholay \& Ameen, 2019; Oliveira, Thomas, Baptista \& Campos, 2017; Qasim \& Abu-Shanab, 2016). Social influence had a significant impact on actual e-payment usage. This finding aligns with de Sena Abrahão, Moriguchi and Andrade (2016); Isaac, Abdullah, Aldholay and Ameen (2019); Junadi (2015); Keong, Ramayah, Kurnia and Chiun (2012), which has identified the effect of effort expectancy on actual usage. For instance, Phan, Tran, Hoang and Dang (2020) found a positive impact of social influence on e-payment usage. In their study, they measured social influence among citizens in Hanoi City of Vietnam. Additionally, Nguyen and Huynh (2018) suggested adding social influence to study e-payment usage. This result also aligns with Chaouali, Yahia and Souiden (2016), who argued that social associations were related to specific behavior. Furthermore, the results showed that the influence of facilitation conditions was positively associated with the actual e-payment usage. Such a finding aligns with much previous research (e.g., Alalwan, Dwivedi \& Rana, 2017; Im, Hong \& Kang, 2011; Kaium, Bao, Alam \& Hoque, 2020; Keong, Ramayah, Kurnia \& Chiun, 2012; Oliveiraa, Fariaa, Thomas \& Popovica, 2014; Teo, Tan, Ooi, Hew \& Yew, 2015; Zhou, 2011). Oh and Yoon (2014) found that the users tend to use the Internet when they feel the resources are available for their use. Therefore, barriers to use like slow access level, unavailability, or service disruption due to the unreliable system would reduce the user's perception of service value. Mobile service providers, therefore, must facilitate conditions to support users (Thakur \& Srivastava, 2014). This study found that the influence of effort expectancy was insignificant, which seems to indicate that when competing with other variables, effort expectancy has lost its significance. This is different from the findings of some studies (Goyal, Maity, Thakur \& Srivastava, 2013; Isaac, Abdullah, Aldholay \& Ameen, 2019; Maillet, Mathieu \& Sicotte, 2015; Riskinanto, Kelana \& Hilmawan, 2017). Among the possible reasons for this difference are that Riskinanto, Kelana and Hilmawan (2017) and Goyal, Maity, Thakur and Srivastava (2013) used perceived ease of use as a construct. Additionally, Maillet, Mathieu and Sicotte (2015) suggested that a mediating variable could impact the relationship.

\section{Conclusion}

In conclusion, this study has identified the facilitating conditions, performance expectancy, and social influence that impacted the actual usage of e-payment. Surprisingly, effort expectancy was not significantly related to the actual usage of e-payment. The study's findings have several implications for managers and point the way towards future research. No prior empirical study has investigated the role of the Unified Theory of Acceptance and Use of Technology model on e-payment usage among Generation Z in Malaysia to the best of the authors' knowledge. These results provide valuable contributions that can help decision-makers formulate or adjust their strategies associated with e-payment usage.

\subsection{Theoretical Implications}

This research offers contributions to both practitioners and researchers. The study explored the association between the UTAUT model, actual usage of e-payments and the continuance intention of e-payment. This study demonstrated the validity and applicability of the UTAUT model in the context of an e-payment device in a developing and emerging economy like Malaysia. According to the best knowledge, this was the first study conducted among Generation $\mathrm{Z}$ in Malaysia to measure the use of e-payments through the UTAUT model. The study further contributes to the knowledge base on e-payments by examining the role of performance expectancy, along with other drivers in the model. A thought-provoking finding contrary to previous results was that effort expectancy had no significant influence on the actual e-payment usage. Perhaps this was related to the fact that members of Generation $\mathrm{Z}$ have been immersed in technology and its applications all their lives.

\subsection{Practical Implications}

This research offers several practical contributions to the understanding of e-payment users. E-payment systems can collect pertinent information about users and their environments. Using this information, e-payment service providers could provide more personalized services to users at the most appropriate place and time. Thus, e-payment could be utilized at anytime from anywhere. These will surely help to retain existing e-payment users among Generation $\mathrm{Z}$ and expand its usage.

\subsection{Limitation and Future Research Directions}

Although this study was a productive examination of the adoption and continuance usage intention of e-payment, several limitations exist. First, this empirical study used a cross-sectional survey method to study members of Generation $\mathrm{Z}$ who 
participated in the study. It would be interesting to focus on longitudinal data to ascertain causal relationships among and between independent and dependent variables or to use multiple cases further to investigate the role of the UTAUT model and e-payment usage. Second, a new study using the proposed framework could consider other variables and add them to the framework. For example, future studies could use other variables such as demographic as a moderator variable for e-payment usage (Nguyen \& Huynh, 2018; Oh \& Yoon, 2014). Third, this research was conducted in a single country, suggesting that replication in a cross-national setting would be useful. Future research projects could study users who use e-payments across different geographical contexts and conduct cross-country and cross-cultural comparisons. Finally, the context of the study was a limitation. The survey instrument was limited to one user setting at one point in time and was limited in terms of broader generalizations. Further research representing different age groups with a more balanced composition is necessary.

\section{Acknowledgements}

We would like to thank you for the School of Business and Management, Institut Teknologi Bandung International Joint Research Program under Grant No. 139/I1.C12/SK/KP/2020. Also, we would like to thank Universiti Malaysia Terengganu and Universiti Sains Malaysia for this excellence collaboration work.

\section{References}

Acheampong, P., Zhiwen, L., Antwi, H. A., Otoo, A. A. A., Mensah, W. G., \& Sarpong, P. B. (2017). Hybridizing an Extended Technology Readiness Index with Technology Acceptance Model ( TAM ) to Predict E-Payment Adoption in Ghana. American Journal of Multidisciplinary Research, 5(2), 172-184. https://doi.org/ISSN: 2356-6191

Al-Qeisi, K., Dennis, C., Alamanos, E., \& Jayawardhena, C. (2014). Website design quality and usage behavior: Unified theory of acceptance and use of technology. Journal of Business Research, 67(11), 2282-2290.

Alalwan, A. A., Dwivedi, Y. K., \& Rana, N. P. (2017). Factors influencing adoption of mobile banking by Jordanian bank customers : Extending UTAUT2 with trust. International Journal of Information Management, 37(3), 99-110.

Anderson, J. C., \& Gerbing, D. W. (1988). Structural Equation Modeling in Practice: A Review and Recommended Two-Step Approach. Psychological Bulletin. https://doi.org/10.1037/0033-2909.103.3.411

Asnakew, Z. S. (2020). Customers ' Continuance Intention to Use Mobile Banking : Development and Testing of an Integrated Model. The Review of Socionetwork Strategies, 0123456789. https://doi.org/10.1007/s12626-020-00060-7

Cao, Q., \& Niu, X. (2019). Integrating context-awareness and UTAUT to explain Alipay user adoption. International Journal of Industrial Ergonomics, 69(October 2017), 9-13. https://doi.org/10.1016/j.ergon.2018.09.004

Chang, C. C., Hung, S. W., Cheng, M. J., \& Wu, C. Y. (2015). Exploring the intention to continue using social networking sites: The case of Facebook. Technological Forecasting and Social Change, 95, 48-56.

Chaouali, W., Yahia, I. B., \& Souiden, N. (2016). The interplay of counter-conformity motivation, social influence, and trust in customers' intention to adopt Internet banking services: The case of an emerging country. Journal of Retailing and Consumer Services, 28, 209-218. https://doi.org/10.1016/j.jretconser.2015.10.007

Cho, V., Cheng, T. C. E., \& Hung, H. (2009). Continued usage of technology versus situational factors: An empirical analysis. Journal of Engineering and Technology Management - JET-M, 26(4), 264-284.

Choi, K., Wang, Y., \& Sparks, B. (2019). Travel app users' continued use intentions: it's a matter of value and trust. Journal of Travel and Tourism Marketing, 36(1), 131-143. https://doi.org/10.1080/10548408.2018.1505580

Chong, A. Y. L., Chan, F. T., \& Ooi, K. B. (2012). Predicting consumer decisions to adopt mobile commerce: Cross country empirical examination between China and Malaysia. Decision Support Systems, 53(1), 34-43.

Chopdar, P. K., \& Sivakumar, V. J. (2019). Understanding continuance usage of mobile shopping applications in India: the role of espoused cultural values and perceived risk. Behaviour and Information Technology, 38(1), 42-64.

de Sena Abrahão, R., Moriguchi, S. N., \& Andrade, D. F. (2016). Intention of adoption of mobile payment: An analysis in the light of the Unified Theory of Acceptance and Use of Technology (UTAUT). RAI Revista de Administração e Inovação, 13(3), 221-230. https://doi.org/10.1016/j.rai.2016.06.003

Escobar-Rodríguez, T., \& Carvajal-Trujillo, E. (2014). Online purchasing tickets for low cost carriers: An application of the unified theory of acceptance and use of technology (UTAUT) model. Tourism Management, 43, $70-88$.

Fedorko, R., Fedorko, I., Riana, I. G., Rigelský, M., Oleárová, M., \& Obšatníková, K. (2018). The impact of selected elements of e-commerce to e-shop recommendation. Polish Journal of Management Studies, 18.

Fornell, C., \& Larcker, D. F. (1981). Evaluating Structural Equation Models with Unobservable Variables and Measurement Error. Journal of Marketing Research, 18(1), 39-50. https://doi.org/10.1177/002224378101800104

Foster, B., Saputra, J., \& Grabowska, M. (2020). Communication strategy planning in influencing the intention to visit: An implication to marketing management. Polish Journal of Management Studies, 22(1), 117-133.

Gao, L., Waechter, K. A., \& Bai, X. (2015). Understanding consumers' continuance intention towards mobile purchase: A theoretical framework and empirical study - A case of China. Computers in Human Behavior, 53, $249-262$.

Garcia, P. R. J. M., Restubog, S. L. D., Ocampo, A. C., Wang, L., \& Tang, R. L. (2019). Role modeling as a socialization mechanism in the transmission of career adaptability across generations. Journal of Vocational Behavior, 111(July 2017), 39-48. https://doi.org/10.1016/j.jvb.2018.12.002

Ginanjar, I. R., Hurriyati, R., Adiwibowo, L., Gaffar, V., \& Saputra, J. (2019). The Role of Supply Chain Management Consumer Attitude as Intervening between Brand Images, Perceived Value and Revisiting Intention. Inernational Journal of Supply Chain Management, 8(4), 901.

Goyal, A., Maity, M., Thakur, R., \& Srivastava, M. (2013). Customer usage intention of mobile commerce in India: An 
empirical study. Journal of Indian Business Research, 5(1), 52-72. https://doi.org/10.1108/17554191311303385

Gupta, K., \& Arora, N. (2019). Investigating consumer intention to accept mobile payment systems through unified theory of acceptance model: An Indian perspective. South Asian Journal of Business Studies, 9(1), 88-114.

Hair Jr, J. F., Babin, B. J., \& Krey, N. (2017). Covariance-based structural equation modeling in the Journal of Advertising: Review and recommendations. Journal of Advertising, 46(1), 163-177.

Henseler, J., Ringle, C. M., \& Sarstedt, M. (2015). A new criterion for assessing discriminant validity in variance-based structural equation modeling. Journal of the Academy of Marketing Science, 43(1), 115-135.

Herrando, C., Jimenez-Martinez, J., \& Martin-De Hoyos, M. J. (2019). Tell me your age and I tell you what you trust: the moderating effect of generations. Internet Research, 29(4), 799-817. https://doi.org/10.1108/IntR-03-2017-0135

Hu, L. T., \& Bentler, P. M. (1999). Cutoff criteria for fit indexes in covariance structure analysis: Conventional criteria versus new alternatives. Structural Equation Modeling: A Multidisciplinary Journal, 6(1), 1-55.

Huang, Y. M. (2020). Students' Continuance Intention Toward Programming Games: Hedonic and Utilitarian Aspects. International Journal of Human-Computer Interaction, 36(4), 393-402. https://doi.org/10.1080/10447318.2019.1647665

Humbani, M., \& Wiese, M. (2019). An integrated framework for the adoption and continuance intention to use mobile payment apps. International Journal of Bank Marketing, 37(2), 646-664. https://doi.org/10.1108/IJBM-03-2018-0072

Im, I., Hong, S., \& Kang, M. S. (2011). An international comparison of technology adoption: Testing the UTAUT model. Information and Management, 48(1), 1-8. https://doi.org/10.1016/j.im.2010.09.001

Isaac, O., Abdullah, Z., Aldholay, A. H., \& Ameen, A. A. (2019). Antecedents and outcomes of internet usage within organisations in Yemen: An extension of the Unified Theory of Acceptance and Use of Technology (UTAUT) model. Asia Pacific Management Review, 24(4), 335-354. https://doi.org/10.1016/j.apmrv.2018.12.003

Junadi, S. (2015). A Model of Factors Influencing Consumer's Intention To Use E-payment System in Indonesia. Procedia Computer Science, 59, 214-220. https://doi.org/https://doi.org/10.1016/j.procs.2015.07.557

Kaium, M. A., Bao, Y., Alam, M. Z., \& Hoque, M. R. (2020). Understanding continuance usage intention of mHealth in a developing country: An empirical investigation. International Journal of Pharmaceutical and Healthcare Marketing, 20194. https://doi.org/10.1108/IJPHM-06-2019-0041

Keong, M. L., Ramayah, T., Kurnia, S., \& Chiun, L. M. (2012). Explaining intention to use an enterprise resource planning ( ERP ) system : an extension of the UTAUT model. Business Strategy Series, 13(4), 173-180.

Khayer, A., \& Bao, Y. (2019). The continuance usage intention of Alipay: Integrating context-awareness and technology continuance theory (TCT). The Bottom Line, 32(3), 211-229. https://doi.org/10.1108/BL-07-2019-0097

Khwaldeh, S. (2020). The impact of mobile hotel reservation system on continuous intention to use in Jordan. Tourism and Hospitality Research, 1-14. https://doi.org/10.1177/1467358420907176

Kijsanayotin, B., Pannarunothai, S., \& Speedie, S. M. (2009). Factors influencing health information technology adoption in Thailand's community health centers: Applying the UTAUT model. International Journal of Medical Informatics, 78(6), 404-416. https://doi.org/10.1016/j.ijmedinf.2008.12.005

Kline, R. B. (2012). Assumptions in structural equation modeling. In R. H. Hoyle (Ed.), Handbook of structural equation modeling (pp. 111-125). The Guilford Press.

Koenig-Lewis, N., Marquet, M., Palmer, A., \& Zhao, A. L. (2015). Enjoyment and social influence : predicting mobile payment adoption. The Service Industries Journal, 35(10), 537-554. https://doi.org/10.1080/02642069.2015.1043278

Korzaan, M., \& Morris, S. A. (2009). Individual characteristics and the intention to continue project escalation. Computers in Human Behavior, 25(6), 1320-1330. https://doi.org/10.1016/j.chb.2009.05.005

Kurniawati, E., Siddiq, A., \& Huda, I. (2020). E-commerce opportunities in the 4.0 era innovative entrepreneurship management development. Polish Journal of Management Studies, 21.

Lee, H. S., Loke, Y. J., \& Tan, A. K. (2013). The demand for e-payments in Malaysia: an examination of usage intensity. Margin: The Journal of Applied Economic Research, 7(4), 371-389.

Liébana-Cabanillas, F., Munoz-Leiva, F., \& Sánchez-Fernández, J. (2018). A global approach to the analysis of user behavior in mobile payment systems in the new electronic environment. Service Business, 12(1), 25-64.

Lin, C., \& Nguyen, C. (2011). Exploring e-payment adoption in Vietnam and Taiwan. Journal of Computer Information Systems, 51(4), 41-52. https://doi.org/10.1080/08874417.2011.11645500

Maillet, É., Mathieu, L., \& Sicotte, C. (2015). Modeling factors explaining the acceptance, actual use and satisfaction of nurses using an Electronic Patient Record in acute care settings: An extension of the UTAUT. International Journal of Medical Informatics, 84(1), 36-47. https://doi.org/10.1016/j.ijmedinf.2014.09.004

Marinković, V., Đorđević, A., \& Kalinić, Z. (2020a). The moderating effects of gender on customer satisfaction and continuance intention in mobile commerce: a UTAUT-based perspective. Technology Analysis \& Strategic Management, 32(3), 306-318.

Marinković, V., Đorđević, A., \& Kalinić, Z. (2020b). The moderating effects of gender on customer satisfaction and continuance intention in mobile commerce: a UTAUT-based perspective. Technology Analysis and Strategic Management, 32(3), 306-318. https://doi.org/10.1080/09537325.2019.1655537

Mensah, I. K., Chuanyong, L., \& Zeng, G. (2020). Factors determining the continued intention to use mobile money transfer services (MMTS) among university students in Ghana. International Journal of Mobile Human Computer Interaction, 12(1), 1-21. https://doi.org/10.4018/IJMHCI.2020010101

Muangmee, C., Kot, S., Meekaewkunchorn, N., Kassakorn, N., \& Khalid, B. (2021). Factors Determining the Behavioral Intention of Using Food Delivery Apps during COVID-19 Pandemics. Journal of Theoretical and Applied Electronic 
Commerce Research, 16(5), 1297-1310.

Muhammad, Z. Saputra, J. Hashim, N. Mohd Nor, Mursyidin, M. (2019). A study of green management practice for reducing annual budget and protecting the environment. 33rd International Business Information Management Association Conference: Education Excellent.

Mun, Y. Y., Jackson, J. D., Park, J. S., \& Probst, J. C. (2006). Understanding information technology acceptance by individual professionals: Toward an integrative view. Information and Management, 43(3), 350-363.

Nguyen, T. D., \& Huynh, P. A. (2018). The roles of perceived risk and trust on e-payment adoption. International Econometric Conference of Vietnam, 926-940.

Odoom, R., \& Kosiba, J. P. (2020). Mobile money usage and continuance intention among micro enterprises in an emerging market - the mediating role of agent credibility. Journal of System and Information Technology.

Ofori, K. S., Boateng, H., Okoe, A. F., \& Gvozdanovic, I. (2017). Examining customers' continuance intentions towards internet banking usage. Marketing Intelligence and Planning, 35(6), 756-773. https://doi.org/10.1108/MIP-11-2016-0214

Oh, J. C., \& Yoon, S. J. (2014). Predicting the use of online information services based on a modified UTAUT model. Behaviour and Information Technology, 33(7), 716-729. https://doi.org/10.1080/0144929X.2013.872187

Oliveira, T., Thomas, M., Baptista, G., \& Campos, F. (2016). Mobile payment: Understanding the determinants of customer adoption and intention to recommend the technology. Computers in Human Behavior, 61, 404-414.

Oliveira, T., Thomas, M., Baptista, G., \& Campos, F. (2017). Mobile payment: Understanding the determinants of customer adoption and intention to recommend the technology. Computers in Human Behavior, 61(2016), $404-414$.

Oliveiraa, T., Fariaa, M., Thomas, M. A., \& Popovica, A. (2014). Extending the understanding of mobile banking adoption: When UTAUT meets TTF and ITM. International Journal of Information Management, 34(5), 689-703.

Osah, O., \& Kyobe, M. (2017). Predicting user continuance intention towards M-pesa in Kenya. African Journal of Economic and Management Studies, 8(1), 36-50. https://doi.org/10.1108/AJEMS-03-2017-148

Ozkan, M., \& Solmaz, B. (2015). Mobile Addiction of Generation Z and its Effects on their Social Lifes. Procedia - Social and Behavioral Sciences, 205, 92-98. https://doi.org/10.1016/j.sbspro.2015.09.027

Phan, H., Tran, M., Hoang, V., \& Dang, T. (2020). Determinants influencing customers' decision to use mobile payment services: The case of Vietnam. Management Science Letters, 10(11), 2635-2646. https://doi.org/10.5267/j.msl.2020.3.029

Poromatikul, C., De Maeyer, P., Leelapanyalert, K., \& Zaby, S. (2019). Drivers of continuance intention with mobile banking apps. International Journal of Bank Marketing, 38(1), 242-262. https://doi.org/10.1108/IJBM-08-2018-0224

Qasim, H., \& Abu-Shanab, E. (2016). Drivers of mobile payment acceptance: The impact of network externalities. Information Systems Frontiers, 18(5), 1021-1034.

Ramayah, T., Cheah, J., Chuah, F., Ting, H., \& Memon, M. A. (2018). Partial least squares structural equation modeling (PLS-SEM) using smartPLS 3.0. Pearson Malaysia Sdn. Bhd.

Riskinanto, A., Kelana, B., \& Hilmawan, D. R. (2017). The Moderation Effect of Age on Adopting E-Payment Technology. Procedia Computer Science, 124, 536-543. https://doi.org/10.1016/j.procs.2017.12.187

Shatto, B., \& Erwin, K. (2017). Teaching Millennials and Generation Z: Bridging the Generational Divide. Creative Nursing, 23(1), 24-2017. https://doi.org/10.1891/1078-4535.23.1.24

Susanto, A., Chang, Y., \& Ha, Y. (2016). Determinants of continuance intention to use the smartphone banking services: An extension to the expectation-confirmation model. Industrial Management and Data Systems, 116(3), 508-525.

Tan, W. K., \& Chen, S. K. (2008). An analysis of the factors influencing success of bank-issued micropayment system in Taiwan. Journal of Systems and Information Technology, 10(1), 5-21. https://doi.org/10.1108/13287260810876867

Tella, A., \& Olasina, G. (2014). Predicting users' continuance intention toward e-payment system: An extension of the technology acceptance model. International Journal of Information Systems and Social Change, 5(1), 47-67.

Teo, A. C., Tan, G. W. H., Ooi, K. B., Hew, T. S., \& Yew, K. T. (2015). The effects of convenience and speed in m-payment. Industrial Management \& Data Systems.

Teoh, W. M. Y., Chong, S. C., Lin, B., \& Chua, J. W. (2013). Factors affecting consumers' perception of electronic payment: an empirical analysis. Internet Research, 23(4), 465-485. https://doi.org/10.1108/IntR-09-2012-0199

Thakur, R., \& Srivastava, M. (2014). Adoption readiness , personal innovativeness , perceived risk and usage intention across customer groups for mobile payment services in India. Internet Research, 24(3), 369-392.

Venkatesh, V., Thong, J. Y., \& Xu, X. (2012). Consumer Acceptance and Use of Information Technology: Extending the Unified Theory of Acceptance and Use of Technology. MIS Quarterly, 36(1), 157-178.

Zhou, T. (2011). Understanding mobile internet continuance usage from the perspectives of UTAUT and flow. Information Development, 27(3), 207-218. https://doi.org/10.1177/0266666911414596

Zhou, T. (2014). Understanding continuance usage intention of mobile internet sites. Universal Access in the Information Society, 13(3), 329-337. https://doi.org/10.1007/s10209-013-0313-4

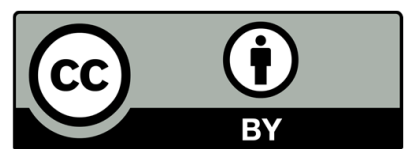

(C) 2022 by the authors; licensee Growing Science, Canada. This is an open access article distributed under the terms and conditions of the Creative Commons Attribution (CC-BY) license (http://creativecommons.org/licenses/by/4.0/) 